\title{
Seasonal changes in organic carbon content in post-arable forest soils
}

\begin{abstract}
The purpose of this work is to determine seasonal changes in the organic carbon content in the mineral topsoil horizon of the Dystric Brunic Arenosols currently used as forest. In addition, the influence of forest age on the soil organic carbon (SOC) content in the A horizon was analyzed. The paper presents the results of studies on temporal changes in the SOC content in the mineral surface horizon of 55-year-old (Sk2) and 13-year-old forest (Sk5) in 2013 and 2014. Soil samples were collected from A horizon once a month between April 2013 and March 2015. Based on the conducted studies, clear seasonal differentiation of the SOC content was observed. Higher contents of SOC in the A horizon of the analyzed soils occurred in the autumn and winter months, and were lower in spring and summer. For Sk2 soil, higher SOC values were observed in autumn and then in winter, which on average were $11.08 \mathrm{~g} \cdot \mathrm{kg}^{-1}$ and $9.61 \mathrm{~g} \cdot \mathrm{kg}^{-1}$ respectively, while lower in spring and summer $\left(8.85 \mathrm{~g} \cdot \mathrm{kg}^{-1}\right.$ and $8.83 \mathrm{~g} \cdot \mathrm{kg}^{-1}$ respectively). Also in the mineral topsoil horizon of Sk5 soil, higher SOC contents were recorded in autumn and winter $\left(8.07 \mathrm{~g} \cdot \mathrm{kg}^{-1}\right.$ and $7.27 \mathrm{~g} \cdot \mathrm{kg}^{-1}$ respectively), and lower in spring and summer $\left(6.19 \mathrm{~g} \cdot \mathrm{kg}^{-1}\right.$ and $6.57 \mathrm{~g} \cdot \mathrm{kg}^{-1}$ respectively). The periodicity of SOC content in plots studied was related to the seasonality of precipitation and temperature. The research also showed that the age of the forest stand influences significantly the content of organic carbon in the A horizon. Higher content of SOC was observed in the A horizon of the 55 years old forest stand (average $9.69 \mathrm{~g} \cdot \mathrm{kg}^{-1}$ ) than on the 13 years old $\left(7.02 \mathrm{~g} \cdot \mathrm{kg}^{-1}\right)$.
\end{abstract}

Keywords: soil organic carbon, seasonal changes, post-arable forest Arenosols

\section{INTRODUCTION}

Soil organic carbon (SOC) is an important contribution to the global balance of this element. The organic carbon resources contained in only 1 meter of the upper layer of soil on the Earth are approximately $1550 \mathrm{Pg}$, which twice exceeds the biomass reserve or resources in the atmosphere (Schlesinger and Andrews 2000, Jobbágy and Jackson 2000, Lal 2008, Lal 2010). Forest soils form as a result of a long-term mutual relationship with the forest stand. The content of SOC depends on the balance between the rate of inflow of fresh debris and decomposition of organic matter. The rate of soil organic matter decomposition depends on many factors: physicochemical and biological properties of soils, climate, soil water content, microorganisms activity and the species composition of plant communities. In soils used as a forest, organic matter is found primarily in surface organic horizon $(\mathrm{O})$ and in a mineral topsoil horizon (A) (Polish Soil Classification 2011). So far, studies on the temporary differentiation of SOC content in soils mainly concern changes over the years (Zak et al. 1990, Zwoliński 1998, Richter et al. 1999, Lal 2000, Post and Kwon 2000, Vesterdal et al. 2002, Smal and Olszewska 2008). Less attention is devoted to seasonal changes (García-Oliva et al. 2003, Yavitt and Wright 2001, Hill 2016). The SOC sequestration studies after afforestation of former arable land carried out by Post and Kwon (2000) and Vesterdal et al. (2002) showed an increase in the content of SOC, especially in the top 5-cm soil layer, but simultaneous reduction in deeper soil layers $(5-15$ and $15-25 \mathrm{~cm})$ with the forest age.

Observations made by Zak et al. (1990) and Richter et al. (1999) and Deng et al. (2016) proved that in the first years after afforestation, there is an initial reduction in the organic matter content in the soil, which may be associated with intensive forest growth in its initial phase with a trace of fresh organic matter entering the soil. Also Lal (2000), Smal and Olszewska (2008), Laganiere et al. (2010) and Deng et al. (2016) noted that the change in the way the soil is managed from forest to agricultural can result in losses of up to $50 \%$ of the carbon stocks after only 5-10 years of cultivation in tropical climate and 40-50 years of farming in temperate climate conditions. Measurements conducted by Zwoliński (1998) in forest soils showed that after 30 years there is a clear transition of organic carbon compounds from litter horizon to the mineral soil horizon and the formation of A horizon. Zak et al. (1990), Post and 
Kwon (2000), Vesterdal et al. (2002) and Ritter (2007) also observed that $30-40$ years after afforestation the content of organic matter in the forest begins to increase noticeably by changing the forest from the $\mathrm{CO}_{2}$ emitter to its reservoir.

The seasonal change in the content of SOC is determined by the cyclic inflow of plant residues to the soil and the dynamics of their transformation in the processes of mineralization and humification (Wuest 2014). In the experiments carried out by García-Oliva et al. (2003), in tropical forests in the western Mexico, seasonal fluctuations in the SOC content were noted. Studies have shown that in the rainy season, there was accumulation of labile nutritional forms that persisted during the dry season and increased the activity of microorganisms in the first days of the rainy season. García-Oliva et al. (2003) also showed that dry season litter samples were characterized by higher SOC and N mineralization than in the rainy seasons. These results suggest that SOC content strongly depends on the seasonality of precipitation. Turner et al. (2015) noticed that especially the biomass of soil microorganisms is subject to strong seasonal fluctuations in relation to the soil moisture. This decreases by about $50 \%$ in the dry season in the tropical forests of Panama. Similar studies were carried out by Wieder and Wright (1995), in which they found that the seasonality of soil moisture controls the distribution of forest litter in tropical wet forests.

Studies conducted by Turner et al. (2015) in the tropical forests of the Republic of Panama showed that, the SOC content decreased during a four-month dry season (January-April), and then rapidly increased during the rainy season. The difference between the average SOC content in the rainy season and the dry season was $16 \%$. Observations by Ryan et al. (2009) showed that the highest SOC content in the soil was recorded in February (1.48\%), while the next measurement made in August showed only 1.15\%. Also, Hill's research (2016) showed clear seasonal differences in changes in SOC content. The rainy season SOC soil content was $223.24 \mathrm{Mg} \cdot \mathrm{ha}^{-1}$ while in the dry season $217.90 \mathrm{Mg} \cdot \mathrm{ha}^{-1}$.

The aim of this work was to determine seasonal changes in the organic carbon content in the mineral topsoil horizon (A) of post-arable Arenosols, which are currently used as forest. Additionally, the influence of forest stand age on the organic carbon content in the A horizon was analyzed.

\section{MATERIALS AND METHODS}

Field investigation

The research was carried out in post-arable soils, currently used as forest, in the village of Skrzynka Wielka, located $21 \mathrm{~km}$ in the north of Stupca city (Wielkopolska province). In this area 8 research plots were distinguished, which represent different age classes of fresh mixed coniferous forest (constituting the first generation of forest), as well as a fallow land and a cultivated field as a reference area, where: Sk1-90 years-old-forest stand, Sk2-55 year-old-forest stand, Sk3-36 years old forest stand, Sk4-21 year-old-forest stand, Sk5-13 years-old-forest stand, Sk6-fallow, Sk717 years-old-forest stand and Sk8 arable land (Fig. 1) (Forest Equipment Manual 2012). The research plot Sk2 was afforested with Scots pine (Pinus sylvestris L.) as a dominant species with admixture of birch (Betu$l a \mathrm{~L}$.). In the case of Sk5 plot the main species was Scots pine with admixture of birch and beech (Fagus L.). Soil samples form A horizon were collected once a month between April 2013 and March 2015. On each study area a plot of $2 \times 2 \mathrm{~m}$ was designated and then it was divided into 25 squares (with a side of $0.4 \mathrm{~m}$ ). Each time 5 soil samples located on the diagonal of the measurement surface were collected: two undisturbed soil samples structure, to determine the soil bulk density and actual soil moisture, and three disturbed soil samples for chemical analyses. During the soil samples collection, a soil temperature measurement was carried out. Meteorological data was obtained from the meteorological station located in Siernicze Wielkie.

In this paper the results of temporal changes in soil organic carbon content in the mineral topsoil horizon of the 55-year-old-forest stand (Sk2) and 13-years-old-forest stand (Sk5) from 2013 to 2014 were presented.

\section{Laboratory methods}

In soil samples taken from mineral topsoil horizons, the following parameters were determined:

- soil texture. The sand fraction was determined by the sieve method, while the finer fraction was determined by Casagrande's hydrometer method in the modification of Prószyński (PN 04032),

- soil organic carbon (SOC) content was determined by dry mineralization using the N/C 3100 JenaAnalytik analyzer. The amount of $\mathrm{CO}_{2}$ emitted during the mineralization was measured with infrared radiation. Due to the lack of carbonates in the soil samples, the obtained carbon results were 


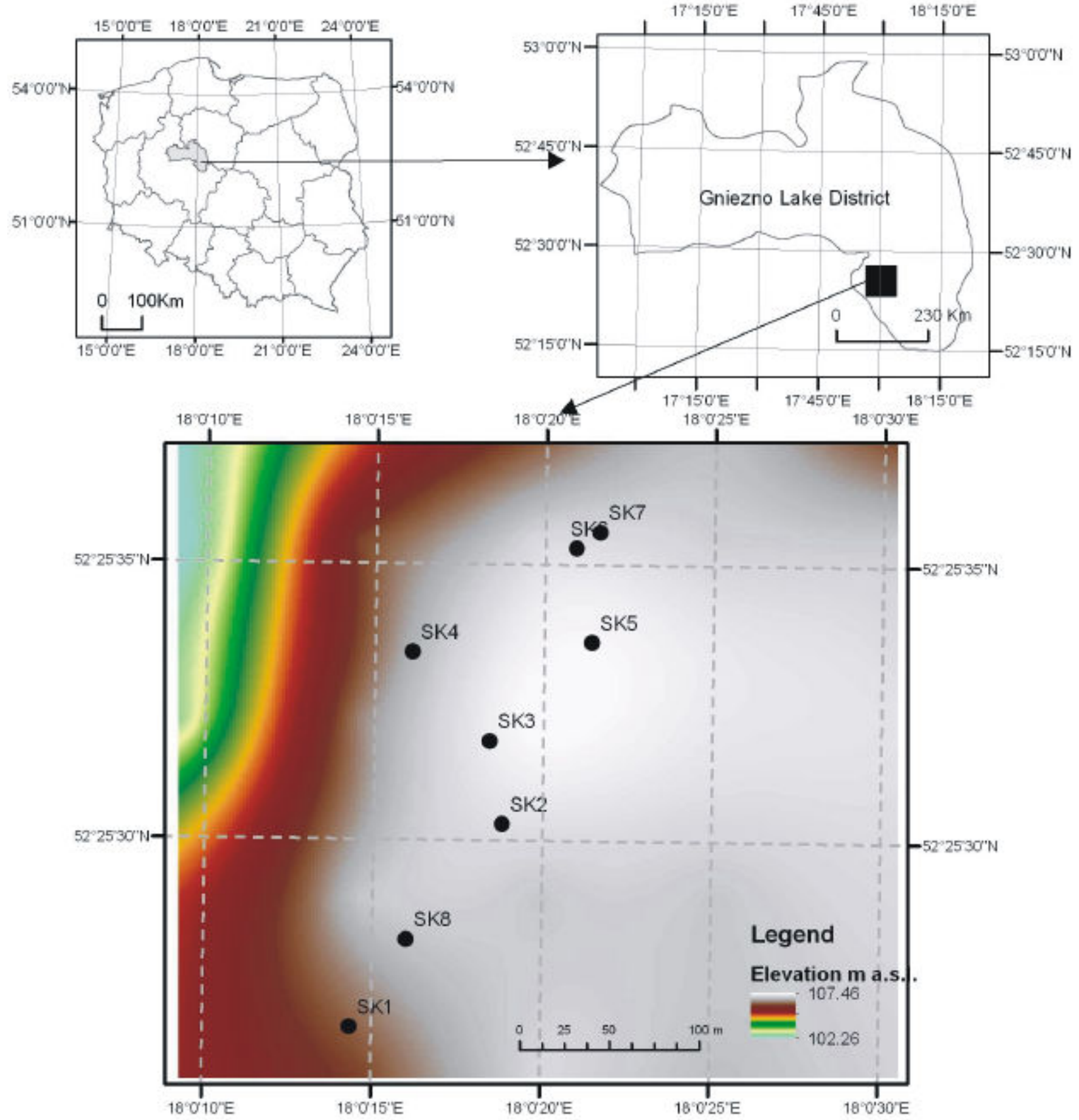

FIGURE 1. Location of the research area and the digital elevation model

synonymous with organic carbon. The content of organic carbon was determined in triplicate, while in the paper results are presented as averaged values,

- the actual soil moisture content was determined by gravimetric method.

\section{Statistical analysis}

Basic statistical measures of position and dispersion were used in the development of data. For each research plot and season, the SOC content distributions were tested for normality using the KolmogorovSmirnov test. Taking into consideration that distribution of SOC content in particular seasons and years was not normal, the non-parametric Kruskal-Wallis test was used. This test was used to compare the SOC content between the analyzed soils as well as between individual years. Statistical analyzes were performed using the Statistica 13.0 program (StatSoft, Inc., USA). 


\section{RESULTS AND DISCUSSION}

The conducted analyses classified soil studied to Dystric Brunic Arenosols (IUSS Working Group WRB, 2015) (Table). The analysed soils are characterized by a well-developed A horizon, which abruptly and smoothly separates from the below endopedones, which is a typical feature of soils previously used for agriculture.

Figure 2 presents temporary changes in SOC content in the mineral topsoil horizon of the soils studied during the research period. The data obtained indicated a repeated increase in organic carbon content in the autumn and winter months and its decrease in the spring and summer period. A pattern of this kind is probably related to decrease in soil temperature and simultaneous growth of soil moisture (Fig. 3-5) during autumn and winter seasons, which limit an intensity of abiotic mineralization. Additionally, we cannot exclude influence of increasing inflow of fresh organic matter in the end of summer and autumn periods (Prusinkiewicz et al. 1974). The

\begin{tabular}{|c|c|c|c|c|c|c|c|}
\hline Horizon & Depth & $\begin{array}{l}\text { Horizon } \\
\text { boundaries }\end{array}$ & Soil colour & $\begin{array}{l}\text { Soil } \\
\text { texture }\end{array}$ & Moisture & $\begin{array}{l}\text { Soil } \\
\text { structure }\end{array}$ & Consistency \\
\hline \multicolumn{8}{|c|}{ Sk2 - Dystric Brunic Arenosols (Ochric) } \\
\hline $\mathrm{O}$ & $0-7$ & AS & - & - & - & - & - \\
\hline $\mathrm{AE}$ & $7-10$ & AS & 10YR 4/2 & $\mathrm{S}$ & $\mathrm{d}$ & $\mathrm{sg}$ & $\mathrm{L}$ \\
\hline $\mathrm{A}$ & $10-25$ & AS & $10 \mathrm{YR} 5 / 3$ & $\mathrm{~S}$ & $\mathrm{~d}$ & $\mathrm{sg}$ & $\mathrm{L}$ \\
\hline Bsv & $25-27$ & $\mathrm{CW}$ & $10 \mathrm{YR} 6 / 3$ & $\mathrm{~S}$ & $\mathrm{~d}$ & $\mathrm{sg}$ & $\mathrm{L}$ \\
\hline $\mathrm{B} 1 \mathrm{v}$ & $27-46$ & $\mathrm{CW}$ & 10YR 6/8 & $\mathrm{S}$ & $\mathrm{d}$ & $\mathrm{sg}$ & $\mathrm{L}$ \\
\hline $\mathrm{B} 2 \mathrm{v}$ & $46-64$ & $\mathrm{CW}$ & $10 \mathrm{YR} 6 / 6$ & $\mathrm{~S}$ & $\mathrm{sm}$ & $\mathrm{sg}$ & $\mathrm{L}$ \\
\hline $\mathrm{C} 1$ & $64-85$ & $\mathrm{CW}$ & $10 \mathrm{YR} 7 / 3$ & $\mathrm{~S}$ & $\mathrm{~m}$ & $\mathrm{sg}$ & $\mathrm{L}$ \\
\hline $\mathrm{C} 2$ & $>85$ & - & $10 \mathrm{YR} 7 / 3$ & $\mathrm{~S}$ & $\mathrm{~m}$ & $\mathrm{sg}$ & $\mathrm{L}$ \\
\hline \multicolumn{8}{|c|}{ Sk5 - Dystric Brunic Arenosols (Ochric) } \\
\hline $\mathrm{O}$ & $0-2$ & AS & - & - & - & - & - \\
\hline $\mathrm{Ap}$ & $2-27$ & AS & $10 \mathrm{YR} 4 / 2$ & $\mathrm{~S}$ & $\mathrm{~m}$ & $1 \mathrm{gr}$ & $\mathrm{L}$ \\
\hline $\mathrm{Bv1}$ & $27-50$ & $\mathrm{CW}$ & 10 YR $5 / 6$ & $\mathrm{~S}$ & $\mathrm{~m}$ & $\mathrm{sg}$ & $\mathrm{L}$ \\
\hline $\mathrm{Bv} 2$ & $50-70$ & $\mathrm{CW}$ & 10YR 6/6 & $\mathrm{S}$ & $\mathrm{m}$ & $\mathrm{sg}$ & VFR \\
\hline $\mathrm{C}$ & $70<$ & - & $10 Y R 4 / 6$ & $\mathrm{~S}$ & $\mathrm{~m}$ & $\mathrm{sg}$ & VFR \\
\hline
\end{tabular}

Explanations: horizon boundaries: $\mathrm{AS}$ - abrupt, smooth; $\mathrm{CW}$ - clear, wavy; soil texture lasses $\mathrm{S}$ - sand; moisture: $\mathrm{d}$ - dry; $\mathrm{sm}$ - slightly moist; $\mathrm{m}$ - moist soil structure: $1 \mathrm{gr}$ - very fine/thin, gr - granular; $\mathrm{sg}$ - single grain consistency: L - loose; VFR - very friable.

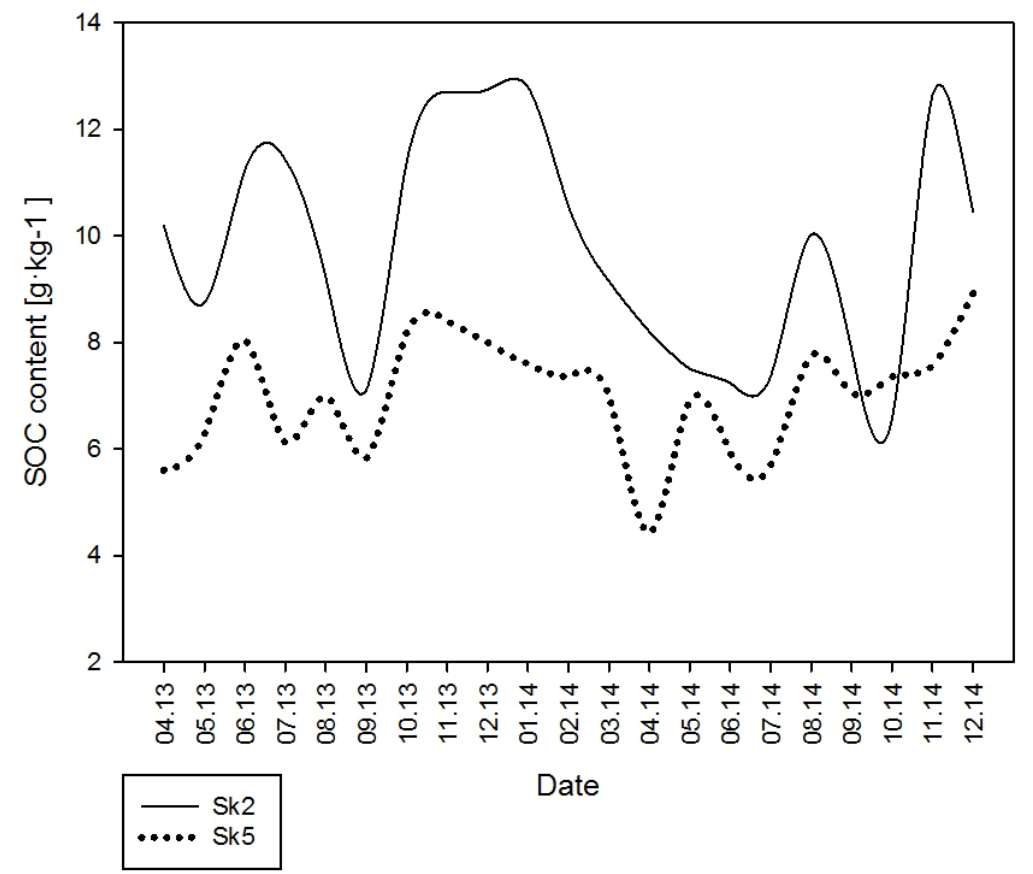

TABLE. Selected soil properties

Sk2 - Dystric Brunic Arenosols (Ochric) 
highest organic carbon content for both $\mathrm{Sk} 2$ and Sk5 plots in 2013 was recorded in November, $12.7 \mathrm{~g} \cdot \mathrm{kg}^{-1}$ and $8.4 \mathrm{~g} \cdot \mathrm{kg}^{-1}$ for Sk2 and Sk5 respectively. In the next year, also the autumn months were characterized by the highest SOC contents for both Sk2-12.64 $\mathrm{g} \cdot \mathrm{kg}^{-1}$
(November), while for Sk5-8.92 $\mathrm{g} \cdot \mathrm{kg}^{-1}$ (December). Also, Turner et al. (2015) conducting research in the tropical forest recorded a significant reduction in SOC content from $5 \%$ observed in November to $4 \%$ in April, followed by a gradual increase in SOC content
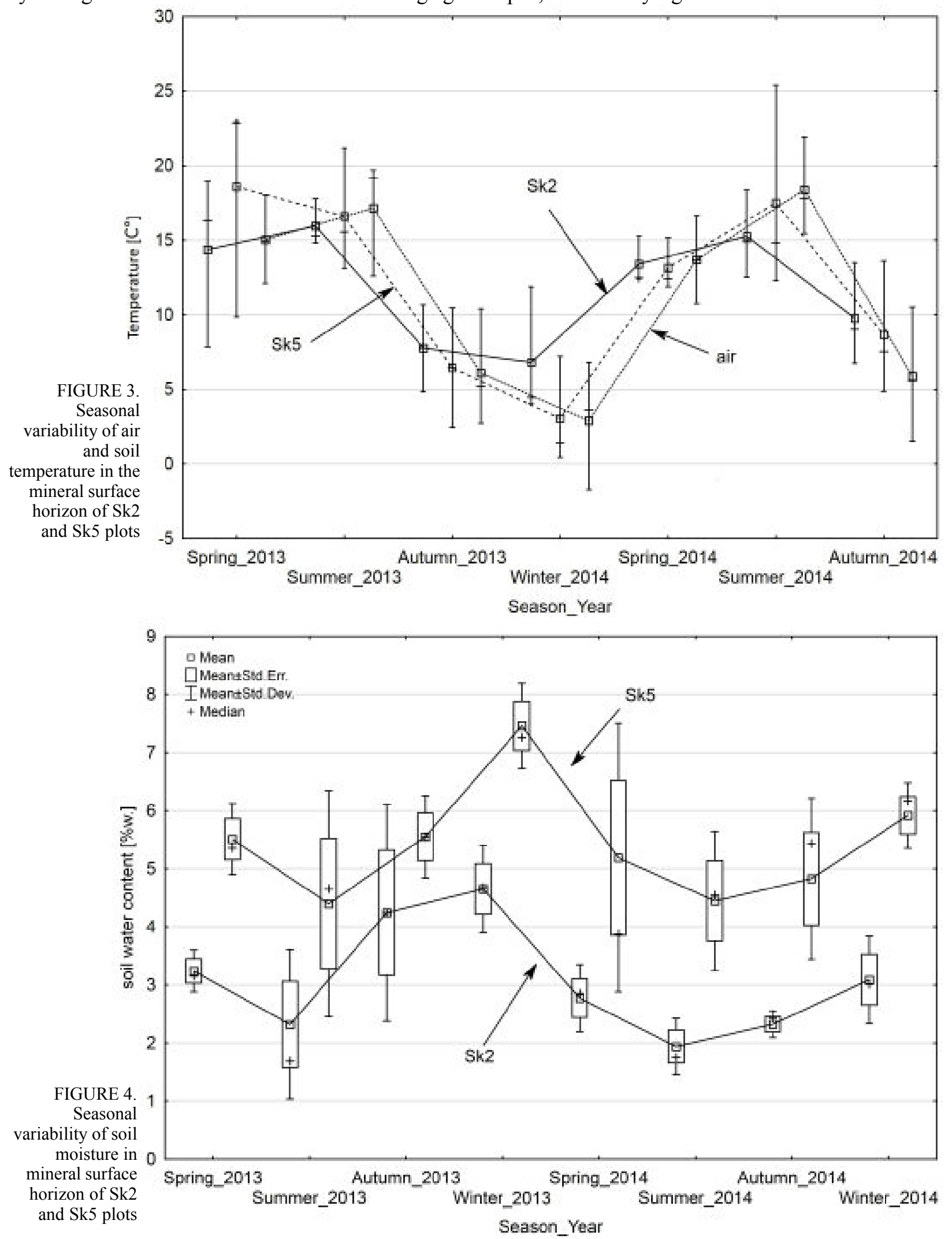
from May to September. Lower SOC content noted for spring $2013\left(10.02 \mathrm{~g} \cdot \mathrm{kg}^{-1}\right.$ and $6.7 \mathrm{~g} \cdot \mathrm{kg}^{-1}$ respectively for $\mathrm{Sk} 2$ and $\mathrm{Sk} 5$ ) was associated with the beginning of the growing season and increasing in microbiological activity, while in the summer of $2013\left(9,1 \mathrm{~g} \cdot \mathrm{kg}^{-1}\right.$ and $6,25 \mathrm{~g} \cdot \mathrm{kg}^{-1}$ for Sk2 and Sk5 respectively) could be associated with an intensive mineralization process, which was favored by higher temperature, lower soil water content and higher microbiological activity. The 2014 showed similar trend in SOC content, the highest value were observed in autumn season. However, in contradiction to the previous year the lowest value of SOC was recorded during spring season (7.5 $\mathrm{g} \cdot \mathrm{kg}^{-1}$ for $\mathrm{Sk} 2$ and $5.9 \mathrm{~g} \cdot \mathrm{kg}^{-1}$ for Sk5). A coarse texture and low clay fraction content $(2 \%$ and $0 \%$ for $\mathrm{Sk} 2$ and $\mathrm{Sk} 5$ respectively) of soil studied ensure highly oxidized environment with little potential to physically protect organic carbon inputs from abiotic mineralization and/or microbial attack. This is probably why the carbon content in these soils responded so clearly to changes in temperature and soil moisture. A significant increase in the content of SOC during autumn period could be a result both a temperature drops and a soil moisture increases (Fig. 3-6). Moreover, the effect of an increase inflow of fresh organic matter to the soil cannot be excluded, Prusinkiewicz et al. (1974) informed that up to $60 \%$ of annual fall of organic residue was observed in October and second, lower maximum amounting up to $15 \%$ occurred in June.

Figures 5 and 7 present the average SOC contents in the mineral topsoil horizon of the analyzed plots in particular seasons and years. In the case of the Sk2 plot, higher SOC values were observed in autumn and then in winter, which on average were respectively, $11.08 \mathrm{~g} \cdot \mathrm{kg}^{-1}$ and $9.61 \mathrm{~g} \cdot \mathrm{kg}^{-1}$, while lower in spring and summer $\left(8.85 \mathrm{~g} \cdot \mathrm{kg}^{-1}\right.$ and $8.83 \mathrm{~g} \cdot \mathrm{kg}^{-1}$ respectively). Also in the Sk5 plot, higher SOC content was recorded in autumn and winter (respectively, 8.07 $\mathrm{g} \cdot \mathrm{kg}^{-1}$ and $7.27 \mathrm{~g} \cdot \mathrm{kg}^{-1}$ ), and lower in spring and summer $\left(6.19 \mathrm{~g} \cdot \mathrm{kg}^{-1}\right.$ and $6.57 \mathrm{~g} \cdot \mathrm{kg}^{-1}$ respectively). Despite the evident seasonality of the SOC content in the plot studied, no statistically significant differences were found between contents of SOC in particular seasons in the Sk2 plot. A similar result was obtained in the case of Sk5, however, in this case the differences in the SOC content were between spring, where the lowest content was observed, and winter

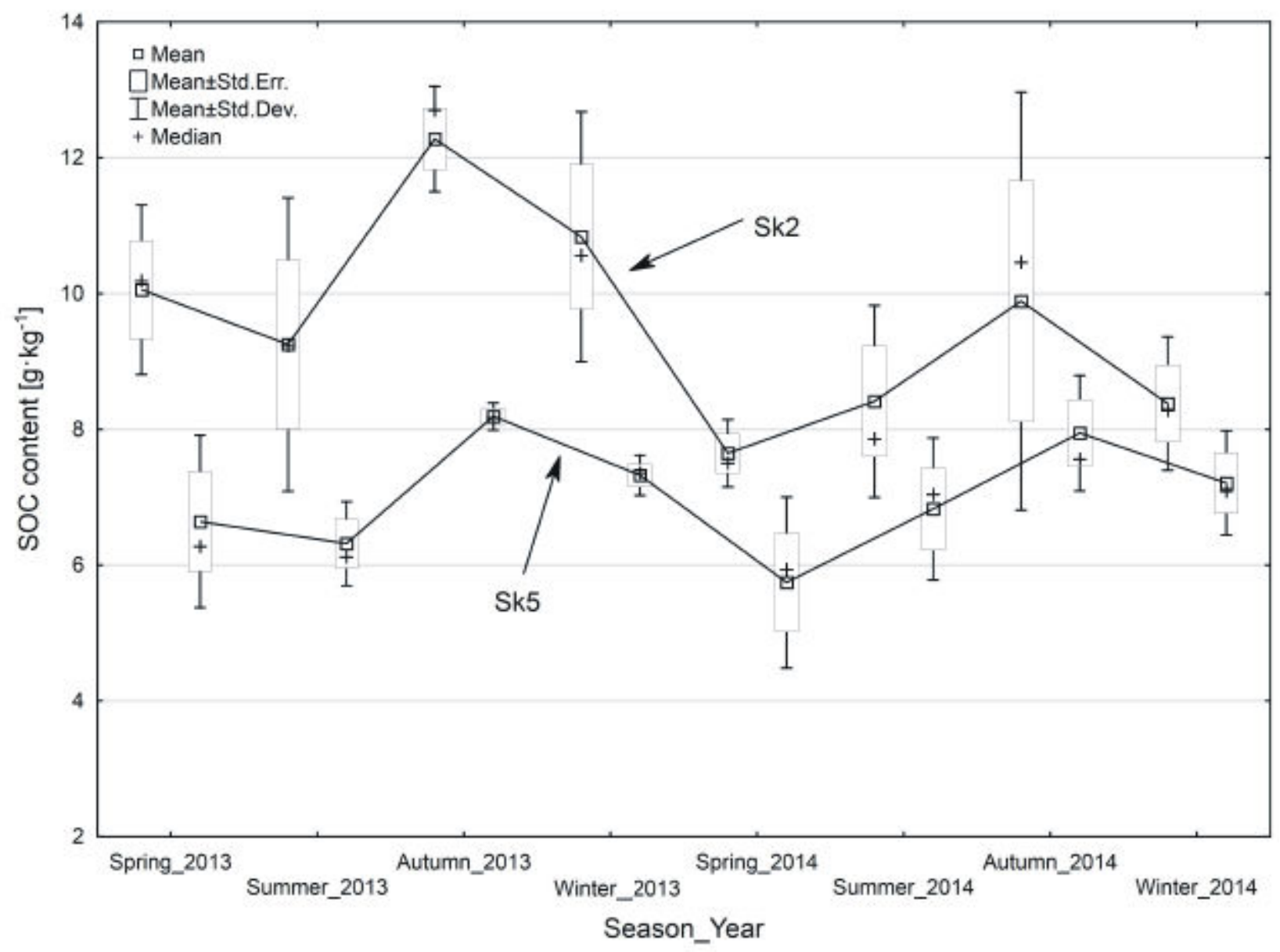

FIGURE 5. Seasonal variability of SOC in the mineral topsoil horizon of Sk2 and Sk5 plots 
FIGURE 6.

The average seasonal content of SOC in the mineral topsoil horizon in Sk2 and Sk5 plots
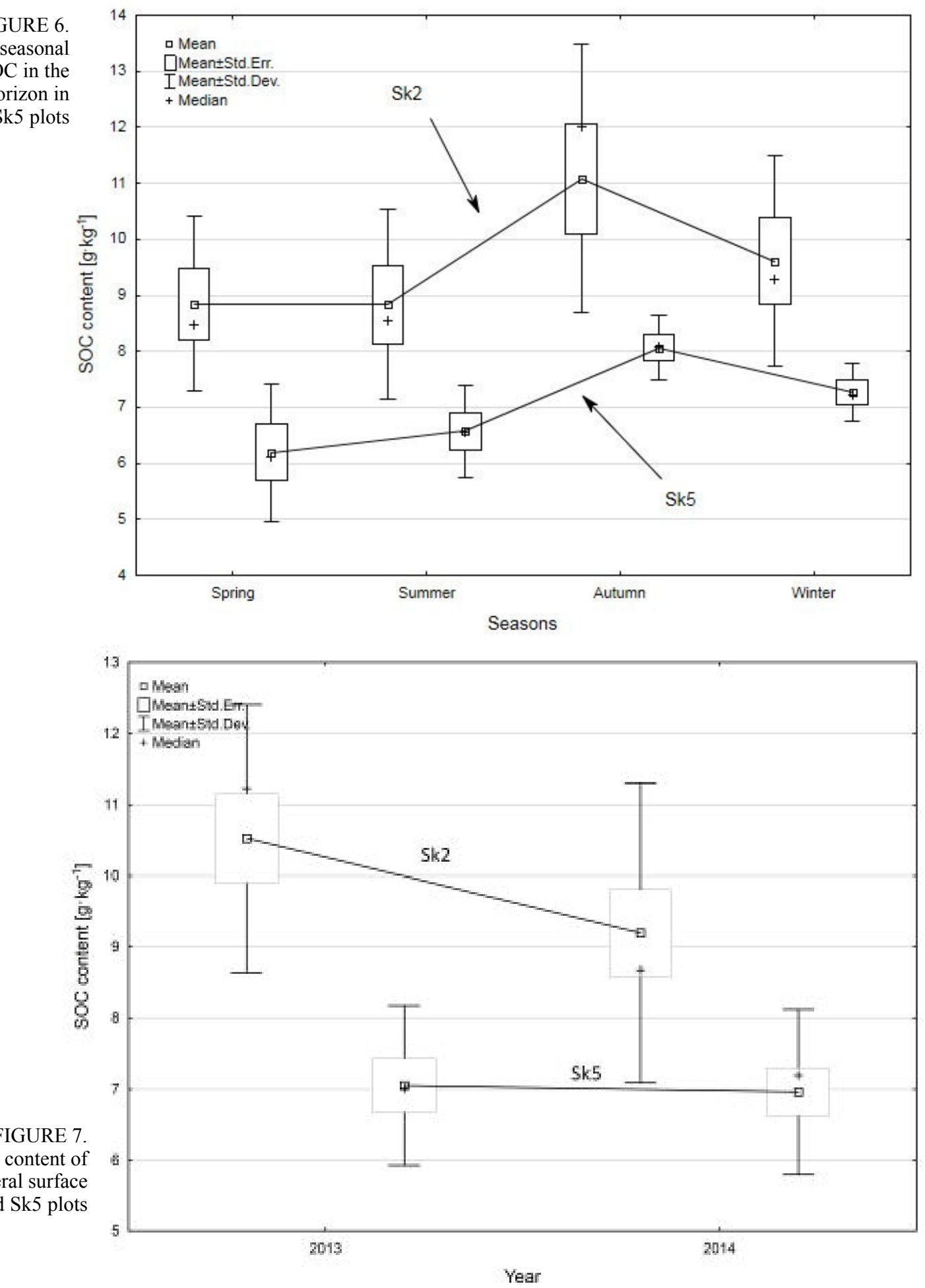

characterized by the highest amounts of SOC. Lack of statistically significant differences in SOC content between particular seasons may be due to the short measurement period and associated with it a small number of sample. Analysing particular years, no significant differences in SOC content between 2013 and 2014 were observed for both Sk2 and Sk5 plots. Higher average annual content of SOC in the surface mineral horizon was noted in $2013\left(10.53 \mathrm{~g} \cdot \mathrm{kg}^{-1}\right.$ and
$7.14 \mathrm{~g} \cdot \mathrm{kg}^{-1}$ for Sk2 and Sk5 respectively) than in 2014 $\left(9.20 \mathrm{~g} \cdot \mathrm{kg}^{-1}\right.$ and $6.96 \mathrm{~g} \cdot \mathrm{kg}^{-1}$ for Sk2 and Sk5 respectively).

Comparing the SOC content between the analyzed plots, it can be concluded that the SOC amount in the mineral surface horizon of the Sk2 was significantly different from the Sk5 (Fig. 8). In the soil epipedon, 13-year-old-forest stand (Sk5) the average SOC content was $7.02 \mathrm{~g} \cdot \mathrm{kg}^{-1}$, while in the A horizon of the 


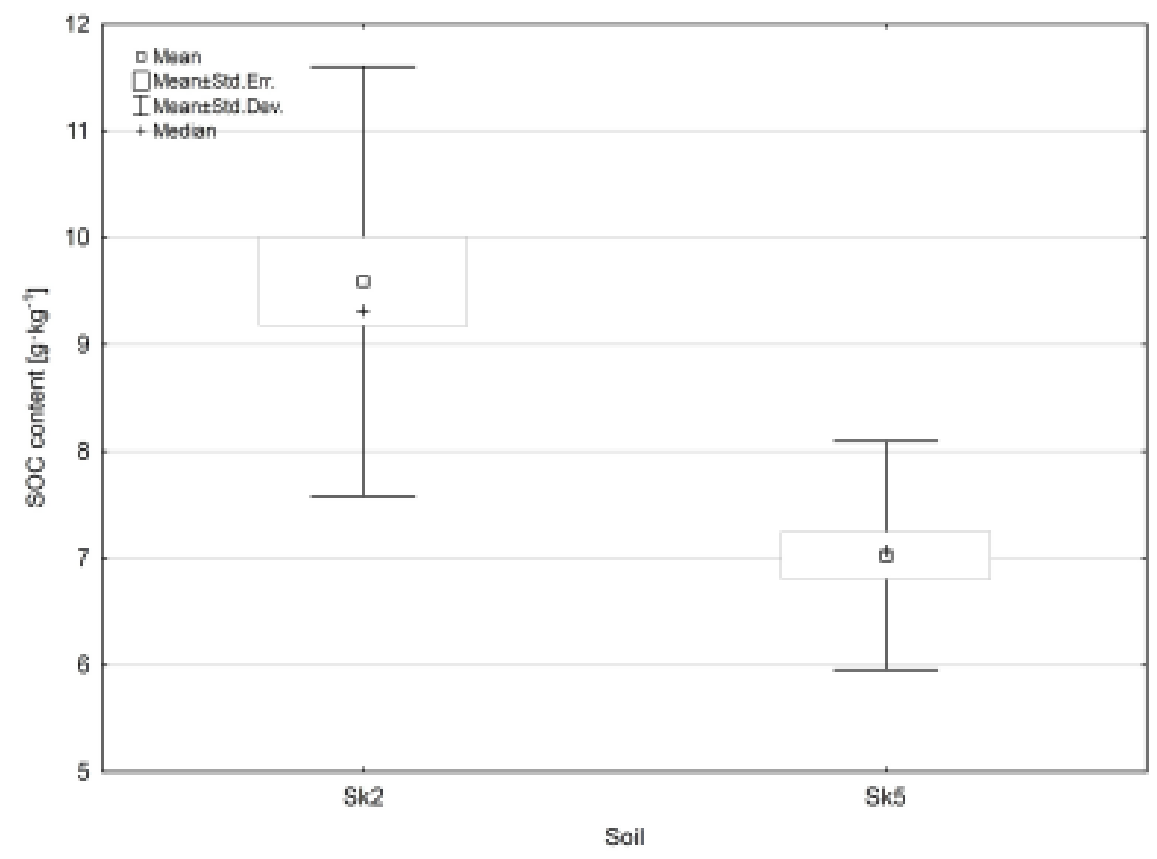

FIGURE 8. The average SOC in the mineral surface horizon in Sk2 and Sk5 plots mation contributed to the higher SOC accumulation in A horizon, additionally $\mathrm{O}$ horizon is also developing. This periodicity caused a greater temporal variability of the SOC content in the Sk2 soil compared to the $\mathrm{Sk} 5$ soil. The coefficient of variation of SOC content in the mineral topsoil horizon of the Sk5 plot was $17 \%$, while in the Sk2 $35 \%$. This temporal variability of the SOC content in the analyzed soils is more related to the variation of soil moisture than to soil temperature. In case of soil moisture, a higher temporal variability was observed in Sk2 than in Sk5, whereas in the case of temperature there was an inverse re- 55-year-old-forest stand (Sk2) this content was significantly higher $9.69 \mathrm{~g} \cdot \mathrm{kg}^{-1}$. Similar results were obtained by Zak et al. (1990), Vesterdal et al. (2002), Ritter (2007) and Laganiere et al. (2010), who also observed an increase of organic carbon in soil with age of forest stands. The analyzed soils were previously used agriculturally, in which the SOC balance in given soil was modified by cultivation and the quantity and quality of the fresh organic matter added to it. The change from agricultural to forest use caused a decrease in the SOC content in the surface horizon in the first years (13-year-old-stand, Sk5) (Fig. 9). An average SOC content during research period noted for 13-year-old forest stand was $7.02 \mathrm{~g} \cdot \mathrm{kg}^{-1}$ and it was visible lower than for arable field $\left(8.52 \mathrm{~g} \cdot \mathrm{kg}^{-1}\right)$. Also Zak et al. (1990), Richter et al. (1999), Smal and Olszewska (2008) and Deng et al. (2016) observed decreased in SOC content during the first 5-15 years after afforestation, followed by a gradual increase of $\mathrm{C}$ stock. They suggested that such pattern could be related to a small inflow of fresh organic matter to the soils from growing and developing forest crop and/or human disturbance leading to strong soil respiration. In consequence in 13-year-oldstand, where probably mineralization process of organic compounds prevails over accumulation process, lower SOC content was noted in comparison to $\mathrm{Sk} 2$. In the 55-year-old-forest stand (Sk2), the increased cyclic inflow of fresh organic matter, and then its transfor- lationship. The values of variation coefficient of soil temperature were $38 \%$ for Sk 2 and $57 \%$ for Sk 5 , while the values variation coefficient of soil moisture was $40 \%$ (Sk2) and 28\% (Sk5) (Fig. 7, Fig. 8). According to Aanderud et al. (2010) and Boerner et al. (2005), SOC content influencing microorganism activity strongly depends on temperature and water content in the soil. In the autumn, low air and soil temperature, despite the simultaneous soil moisture increase, could reduce the enzymatic activity of soils and increase SOC accumulation. Comparing the water content between the plots studied, it can be concluded on the basis of the Kruskal-Wallis test that the amount of water in the mineral topsoil horizon of the

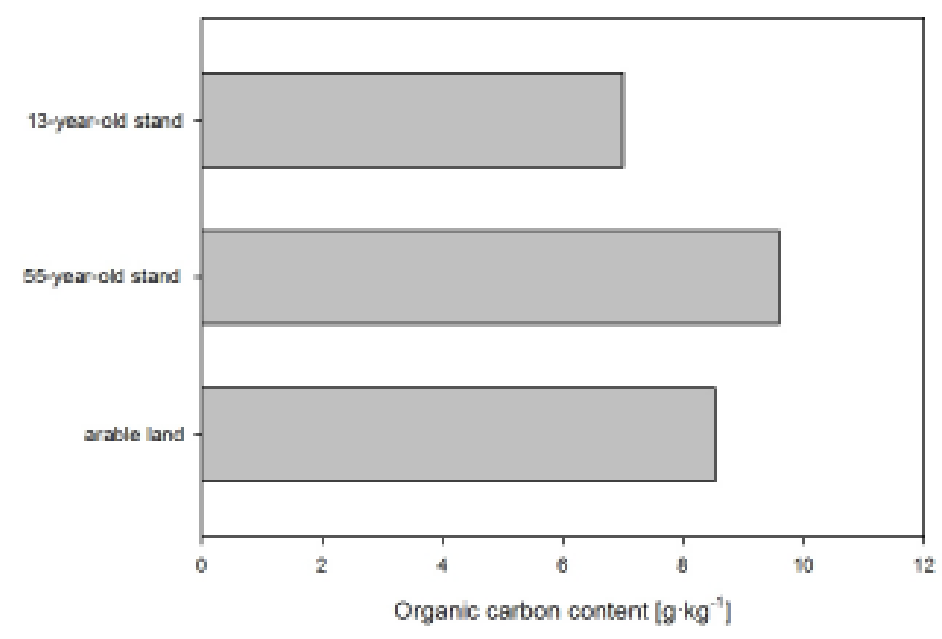

FIGURE 9. The comparison of average content of soil organic carbon in mineral topsoil horizon among studied forest stands and arable land 
Sk2 soil significantly differed from the Sk5 plot. The average soil water content during research period for the Sk2 plot was 3.1\% (weight), while in the Sk5-5.4\%. The average annual water content in the $\mathrm{Sk} 2$ during study period decreased and amounted from $3.3 \%$ in 2013 to $2.8 \%$ in 2014. This was related to the seasonal distribution of atmospheric precipitation (Fig. 9).

The annual sums of precipitation for 2013-2014 period were 614 and $473 \mathrm{~mm}$, respectively. According to Kaczorowska (1962) on the basis of yearly amount of precipitation studied years can be classified as average in 2013 and in a dry year 2014 (Fig. 9). When confronting the results of SOC content in Sk2 and Sk5 with the annual amount of precipitation some dependence could be found. In the dry year (2014), the lower soil water content contributed to the reduction of carbon content in the Sk2 and Sk5 plots. According to Błońska (2011), in the soil exposed to direct sunlight, as a result of the lack of a tight plant cover, there is a marked decrease in enzymatic activity with simultaneous accelerated mineralization of organic matter as a result of, among others, high soil moisture variability.

\section{CONCLUSIONS}

The obtained results of seasonal changes in soil organic carbon content allow us to formulate the following statements and conclusions:

1. The age of the forest stand significantly affects the content of soil organic carbon in the mineral surface horizon. The average SOC content in the mineral topsoil horizon for the 55-year-old-forest stand was $9.69 \mathrm{~g} \cdot \mathrm{kg}^{-1}$ while for the 17 -year-oldforest stand $7.02 \mathrm{~g} \cdot \mathrm{kg}^{-1}$.

2. Temporary changes in SOC content in the mineral surface horizon of post-arable forest soils are characterized by evident seasonality. Higher SOC content in the surface horizon occurs in the autumn and winter months, while it is lower in spring and summer.

3. The periodicity of SOC content in forest soils is related to the seasonality of meteorological conditions. In the dry year (2014), a small amount of precipitation led into lower soil moisture and reduce the SOC accumulation in soil surface horizons.

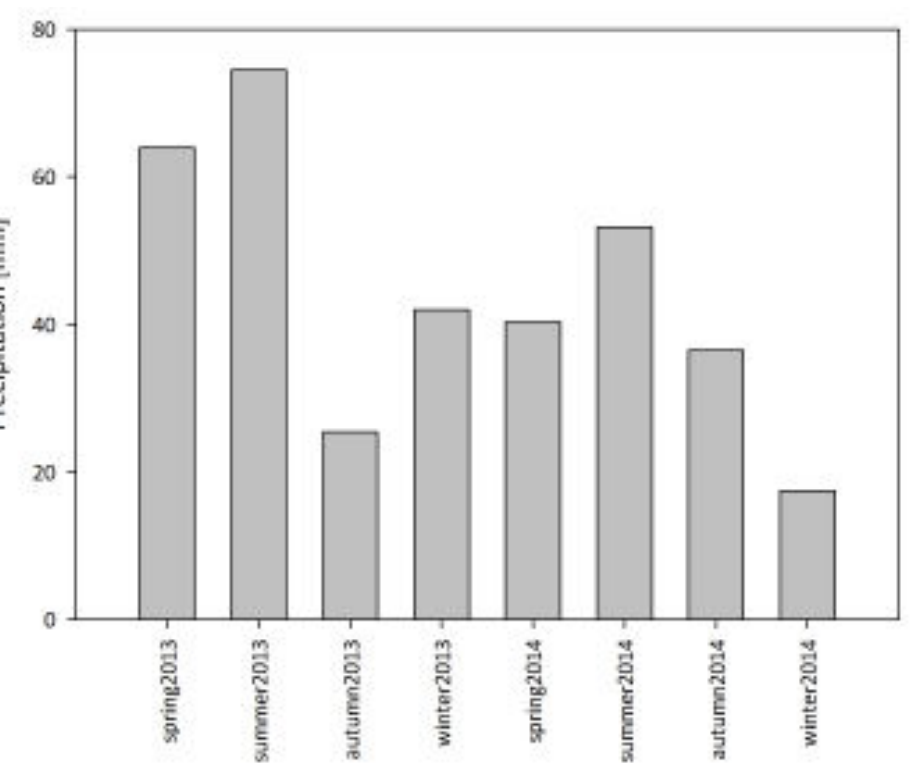

FIGURE 10. Seasonal sum of precipitation for 2013-2014 period

\section{REFERENCES}

Aanderud Z.T., Richards J.H., Svejcar T., James J.J., 2010. A shift in seasonal rainfall reduces soil organic carbon storage in a cold desert. Ecosystems 13(5): 673-682.

Błońska E., 2011. Soil enzyme activity as an indicator of changes in forest soil. Polish Journal of Soil Science 44(1): $75-80$.

Boerner R.E.J., Brinkman J.A., Smith A., 2005. Seasonal variations in enzyme activity and organic carbon in soil of a burned and unburned hardwood forest. Soil Biology and Biochemistry 37(8): 1419-1426.

Deng L., Zhu G-Y., Tang Z-S., Shanggun Z-P., 2016. Global patterns of the effects of land-use changes on soil carbon stock. Global Ecology and Conservation 5: 127-138.

IUSS Working Group WRB. 2015. World Reference Base for Soil Resources 2014, update 2015 International soil classification system for naming soils and creating legends for soil maps. World Soil Resources Reports No. 106. FAO, Rome.

Forest Equipment Manual (Instrukcja Urządzania Lasu), CILP Warszawa 2012, part I: 30-34 (in Polish).

García-Oliva F., Sveshtarova B., Oliva M., 2003. Seasonal effects on soil organic carbon dynamics in a tropical deciduous forest ecosystem in western Mexico. Journal of Tropical Ecology 19(2): 179-188.

Hill P., 2016. Analysis of seasonal soil organic carbon content at Bukit Jeriau Forest, Fraser Hill, Pahang. Malaysian Journal of Analytical Sciences 20(2): 452-460.

Jobbágy E.G., Jackson R.B., 2000. The vertical distribution of soil organic carbon and its relation to climate and vegetation. Ecological Applications 10(2): 423-436.

Kaczorowska Z., 1962. Precipitation in Poland in long-period averages. Geographical Studies 33 (in Polish with English summary).

Laganiere J., Angers D.A., Pare D., 2010. Carbon accumulation in agricultural soils after aforestation: a meta-analysis. Global Change Biology 16(1): 439-453. 
Lal R., 2000. Soil carbon and the accelerated greenhouse effect. (Wegiel glebowy i nasilenie efektu cieplarnianego). Zeszyty Edukacyjne. Rolnictwo Polskie i Ochrona Jakości Wody (06): 22-36 (in Polish).

Lal R., 2008. Carbon sequestration. Philosophical Transactions of the Royal Society B: Biological Sciences 363(1492): $815-830$.

Lal R., 2010. Managing soil and ecosystems for mitigating anthropogenic carbon emissions and advancing global food security. Bioscience Vol. 60, No. 9: 708-721.

Polish Soil Classification (Systematyka Gleb Polski), 2011. Roczniki Gleboznawcze - Soil Science Annual 62(3): 1-193 (in Polish with English summary).

Post W.M., Kwon K.C., 2000. Soil carbon sequestration and land-use change: process and potential. Global Change Biology 6(3): 317-327.

Prusinkiewicz Z., Dziadowiec H., Jakubusek M., 1974. Return to soil of elements - biogens with leaf fall in deciduous and mixed forest on loose sand soils. Roczniki Gleboznawcze Soil Science Annual 25(3): 237-245 (in Polish with English summary).

Ritter E., 2007. Carbon, nitrogen and phosphorus in volcanic soils following afforestation with native birch (Betula pubescens) and introduced larch (Larix sibirica) in Iceland. Plant and Soil 295(1-2): 239-251.

Richter D.D., Markewitz D., Trumbore S.E., Wells C.G., 1999. Rapid accumulation and turnover of soil carbon in a re-establishing forest. Nature 400(6739): 56-58.

Ryan J., Masri S., Singh M., 2009. Seasonal changes in soil organic matter and biomass and labile forms of carbon as influenced by crop rotations. Communications in soil science and plant analysis 40(1-6): 188-199.
Schlesinger W.H., Andrews J.A., 2000. Soil respiration and the global carbon cycle. Biogeochemistry 48(1): 7-20.

Smal H., Olszewska M., 2008. The effect of afforestation with Scots pine (Pinus silvestris L.) of sandy post-arable soils on their selected properties. II. Reaction, carbon, nitrogen and phosphorus. Plant and Soil 305(1-2): 171-187.

Turner B.L., Yavitt J.B., Harms K.E., Garcia M.N., Wright S.J., 2015. Seasonal changes in soil organic matter after a decade of nutrient addition in a lowland tropical forest. Biogeochemistry 123(1-2): 221-235.

Vesterdal L., Ritter E., Gundersen P., 2002. Change in soil organic carbon following afforestation of former arable land. Forest Ecology and Management 169(1-2): 137-147.

Wieder R.K., Wright S.J., 1995. Tropical forest litter dynamics and dry season irrigation on Barro Colorado ILand, Panama. Ecology 76(6): 1971-1979.

Wuest S., 2014. Seasonal variation in soil organic carbon. Soil Science Society of America Journal 78(4): 1442-1447.

Yavitt J.B., Wright S.J., 2001. Drought and irrigation effects on fine root dynamics in a tropical moist forest, Panama. Biotropica 33(3): 421-434.

Zak D.R., Grigal D.F., Gleeson S., Tilman D., 1990. Carbon and nitrogen cycling during old-field succession: constraints on plant and microbial biomass. Biogeochemistry 11(2): 111-129.

Zwoliński J., 1998. The carbon cycle in pine forests. (Obieg węgla w borach sosnowych). Prace IBL (A), 862: 141-155 (in Polish).

Received: August 10, 2018

Accepted: January 7, 2019

Associated editor: A. Lachacz

\section{Sezonowe zmiany zawartości węgla organicznego w porolnych glebach leśnych}

Streszczenie: Celem pracy było określenie sezonowych zmian zawartości węgla organicznego w poziomie próchnicznym porolnych gleb rdzawych (Dystric Brunic Arenosols), które obecnie użytkowane są jako las. Ponadto analizie poddano wpływ wieku drzewostanu na zawartość węgla organicznego $\left(\mathrm{C}_{\mathrm{org}}\right)$ w poziomie próchnicznym. W pracy zaprezentowano wyniki badań czasowych zmian zawartości $\mathrm{C}_{\text {org }}$ w poziomie próchnicznym gleb rdzawych drzewostanu 55-letniego (Sk2) oraz 13-letniego (Sk5) w latach 2013 i 2014. Próbki do badań pobierano raz w miesiącu z poziomu akumulacyjno-próchnicznego w okresie od kwietnia 2013 do marca 2015. Na podstawie przeprowadzonych badań zaobserwowano wyraźne sezonowe zróżnicowanie zawartości $\mathrm{C}_{\text {org }}$. Najwyższe zawartości $\mathrm{C}_{\text {or }}$ w poziomie próchnicznym analizowanych gleb występowały w miesiącach jesiennych i zimowych, natomiast najniższe wiosną i latem. Dla gleby Sk2, najwyższe wartości $\mathrm{C}_{\mathrm{org}}$ obserwowano jesienią, a następnie zimą, które kolejno średnio wynosiły: $11,08 \mathrm{~g} \cdot \mathrm{kg}^{-1}$ i $9,61 \mathrm{~g} \cdot \mathrm{kg}^{-1}$, natomiast najniższe wiosną i latem (odpowiednio: $8,85 \mathrm{~g} \cdot \mathrm{kg}^{-1} \mathrm{i} 8,83 \mathrm{~g} \cdot \mathrm{kg}^{-1}$ ). Również w poziomie próchnicznym gleby Sk5 najwyższe zawartości $\mathrm{C}_{\text {org }}$ odnotowano jesienią i zimą (kolejno: $8,07 \mathrm{~g} \cdot \mathrm{kg}^{-1} \mathrm{i} 7,27 \mathrm{~g} \cdot \mathrm{kg}^{-1}$ ), a najniższe wiosna i latem (kolejno: $6,19 \mathrm{~g} \cdot \mathrm{kg}^{-1}$ i $6,57 \mathrm{~g} \cdot \mathrm{kg}^{-1}$ ). Obserwowana zmienność zawartości wegla organicznego związana była $\mathrm{z}$ sezonowością warunków meteorologicznych (opadów atmosferycznych i temperatury). Przeprowadzone badania wykazały również, że wiek drzewostanu wpływa istotnie na zawartość węgla organicznego w poziomie próchnicznym. Wyższymi zawartościami $\mathrm{C}_{\text {org }}$ charakteryzował się poziom próchniczny 55-letniego drzewostanu (średnio 9,69 $\mathrm{g} \cdot \mathrm{kg}^{-1}$ ) aniżeli lasu 13-letniego $\left(7.02 \mathrm{~g} \cdot \mathrm{kg}^{-1}\right)$.

Stowa kluczowe: węgiel organiczny gleb, zmiany sezonowe, porolne gleby rdzawe 